DOI: https://doi.org/10.24127/ajpm.v9i3.2919

\title{
PENGARUH PENDEKATAN SAINTIFIK TERHADAP KEMAMPUAN BERPIKIR KRITIS MATEMATIS PADA SISWA SMP NEGERI 2 MERAUKE
}

\author{
Nidya Ucisaputri ${ }^{1}$, Nurhayati ${ }^{2}$, Sadrack Luden Pagiling $^{3 *}$ \\ 1,2,3 Universitas Musamus Merauke, Merauke, Indonesia \\ *Corresponding author. Jl. Kamizaun Mopah Lama, 99611, Merauke, Indonesia. \\ E-mail: $\quad \underline{\text { nidya.uci@gmail.com }}^{1)}$ \\ nurhayati_fkip@unmus.ac.id ${ }^{2)}$ \\ pagiling_fkip@unmus.ac.id ${ }^{3 *)}$
}

\begin{abstract}
Abstrak
Tujuan penelitian ini yaitu untuk mengetahui pengaruh pendekatan saintifik terhadap kemampuan berpikir kritis matematis pada siswa kelas VIII SMP Negeri 2 Merauke. Penelitian ini merupakan penelitian eksperimen dengan one-group pretest-posttest design. Tempat dilaksanakannya penelitian ini yaitu di SMP Negeri 2 Merauke. Populasi pada penelitian ini adalah seluruh kelas VIII SMP Negeri 2 Merauke. Pengambilan sampel menggunakan teknik cluster random sampling dan diperoleh sampel yaitu kelas VIII H yang berjumlah 21 siswa. Hasil penelitian mengindikasikan bahwa $n$-gain score berada pada kategori sedang yaitu 0,40 , sedangkan hasil uji hipotesis diperoleh $t_{\text {hitung }}=16,965$ lebih dari $t_{\text {tabel }}=$ 2,086 yang berarti bahwa $H_{0}$ ditolak dan $H_{a}$ diterima. Maka dapat disimpulkan bahwa terdapat pengaruh pendekatan saintifik terhadap kemampuan berpikir kritis matematis pada siswa kelas VIII SMP Negeri 2 Merauke.
\end{abstract}

Kata kunci: Kemampuan berpikir kritis matematis; pendekatan saintifik.

\begin{abstract}
The purpose of this study is to determine the effect of a scientific approach to the ability to think critically mathematical students of class VIII SMP Negeri 2 Merauke. This research is an experimental research with one-group pretest-posttest design. The place of this research is at SMP Negeri 2 Merauke. The population in this study were all class VIII of SMP Negeri 2 Merauke. Sampling using cluster random sampling techniques and obtained samples of class VIII H, amounting to 21 students. The results indicate that the n-gain score is in the medium category of 0,40, while the hypothesis test results obtained $t_{\text {count }}=16,965$ more than $t_{\text {table }}=2,086$ which means that $H_{0}$ is rejected and $H_{a}$ is accepted. Then it can be concluded that there is an influence of the scientific approach to the ability to think critically mathematical students of class VIII SMP Negeri 2 Merauke.
\end{abstract}

Keywords: Mathematical critical thinking skills; scientific approach.

This is an open access article under the Creative Commons Attribution 4.0 International License

\section{PENDAHULUAN}

Berpikir kritis merupakan salah satu bagian kecakapan hidup di era industri 4.0 yang menuntut setiap orang untuk bertindak dan mengambil keputusan dengan cermat dan cepat. Untuk menyikapi hal tersebut, maka penting bagi setiap orang untuk memiliki kemampuan berpikir kritis.
Hal ini terkait bagaimana seseorang mengolah atau memproses informasi yang diperoleh agar tidak menerima secara langsung apa yang diperoleh dari sumber yang belum diketahui keabsahannya. Pernyataan ini sejalan dengan (Kalelioğlu \& Gülbahar, 2013; Kriel, 2013; Miatun \& Khusna, 2020; Sulistyorini \& Napfiah, 2019) yaitu 
setiap orang penting untuk mempunyai kompetensi memadai dalam berpikir kritis.

Berpikir kritis ialah suatu aktivitas mental untuk menarik kesimpulan yang logis tentang sesuatu yang dipercayai dan dilakukan (As'ari, 2014). Pendapat senada dikemukakan juga oleh Kusmanto yaitu berpikir kritis diartikan sebagai kemampuan siswa dalam mempertimbangkan sesuatu dan membuat kesimpulan yang tepat berdasarkan aturan logika serta dapat dibuktikan kebenarannya (valid) sesuai dengan pengetahuan yang telah diketahui sebelumnya (Kusmanto, 2014). Seseorang yang berpikir kritis memiliki kepekaan atas informasi atau kondisi yang dialaminya, dan akan memberikan respons kepada informasi atau kondisi tersebut (Fachrurazi, 2011). Berdasarkan beberapa pengertian yang telah dijelaskan maka berpikir kritis disimpulkan sebagai suatu aktivitas mental dalam menyelesaikan masalah yang bertujuan untuk menarik kesimpulan yang logis dan dapat dibuktikan kebenarannya (valid). Sedangkan kemampuan berpikir kritis berarti kesanggupan seseorang menggunakan aktivitas mental dalam menyelesaikan masalah yang bertujuan untuk membuat kesimpulan yang logis dan valid.

Kemampuan berpikir kritis ini mempermudah siswa mencari penyelesaian soal secara refektif (Asmar \& Delyana, 2020; Hidayat \& Sari, 2019; Rochmad, Agoestanto, \& Kurniasih, 2016). Akan tetapi, kenyataan di sekolah menunjukkan bahwa kemmapuan berpikir kritis siswa belum maksimal. Dari observasi awal di SMP Negeri 2 Merauke terlihat bahwa kemampuan berpikir kritis siswa masih kurang maksimal sehingga siswa belum memenuhi kriteria dalam berpikir kritis yang sangat diperlukan untuk menyelesaikan soal. Hasil observasi terhadap pekerjaan siswa mengindikasikan bahwa terdapat dua siswa mampu memahami soal dengan penulisan model matematika yang tepat namun salah dalam penulisan jawaban akhir, sembilan siswa tidak dapat menuliskan model matematika, dan satu siswa mampu menyelesaikan soal namun tidak dapat membuat kesimpulan akhir, serta delapan belas siswa yang tidak memahami soal ditandai dengan tidak menyelesaikan soal. Hal ini didudukung dari hasil wawancara dengan guru matematika SMP Negeri 2 Merauke, diperoleh informasi bahwa pada proses pembelajaran siswa masih kesulitan untuk mengerjakan soal terutama pada soal yang memerlukan kemampuan menganalisis dan memecahkan masalah.

Guru di SMP 2 Merauke belum memfasilitasi siswa untuk berpikir dalam memgonstruksi pengetahuan atau pemahaman sendiri. Siswa belum diberikan kesempatan untuk menemukan atau melakukan investigasi dalam pembelajaran di kelas. Dengan kata lain, pembelajaran masih terpusat pada guru sehingga tidak memungkinkan siswa untuk berpikir kritis.

Salah satu pendekatan pembelajaran yang dapat memfasilitasi berpikir kritis siswa adalah pendekatan saintifik. Pendekatan saintifik ini memuat aktivitas yang terdiri atas mengamati, menanya, mencoba, menalar, dan mengomunikasikan. Kelima langkah pada pendekatan saintifik dapat melatih berpikir kritis siswa.

Beberapa peneliti sebelumnya (Rochmad et al., 2016; Siti, 2020) telah mendokumentasikan tentang berpikir kritis. Hasil penelitian (Rochmad et al., 
2016) mengungkapkan bahwa pada saat memecahkan masalah matematika siswa melakukan aktivitas bertanya, memprediksi, dan menjelaskan. Penelitian Asmi, Fahinu, dan La Arapu (2015) menyatakan pembelajaran dengan menggunakan pendekatan saintifik mampu meningkatkan kemampuan berpikir kritis siswa kelas VII SMP Negeri 2 Kendari. Oleh karena itu, berpikir kritis mempunyai hubungan dengan proses pembelajaran yang berlangsung yaitu guru mempersiapkan siswa agar dapat menyelesaikan masalah. Berpikir kritis dapat dibiasakan kepada siswa melalui rancangan pembelajaran yang memuat aktivitas yang diperlukan siswa untuk mencapai tujuan pembelajaran. Berdasarkan masalah yang telah diuraikan, penelitian ini bertujuan untuk untuk mengetahui pengaruh pendekatan saintifik terhadap kemampuan berpikir kritis matematis pada siswa kelas VIII SMP Negeri 2 Merauke.

\section{METODE PENELITIAN}

Penelitian eksperimen ini menggunakan one-group pretestposttest design. Desain penelitian dapat disajikan pada Tabel 1.

Tabel 1. Desain Penelitian

\begin{tabular}{|c|c|c|}
\hline & $O_{1}$ & $\mathrm{O}_{2}$ \\
\hline \multicolumn{3}{|c|}{ Keterangan: } \\
\hline & & $\begin{array}{l}\text { kemampuan berpikir kritis } \\
\text { matematis siswa sebelum } \\
\text { diterapkan pendekatan saintifik }\end{array}$ \\
\hline $\mathrm{X}$ & $=$ & penerapan pendekatan saintifik \\
\hline $\mathrm{O}_{2}$ & $=$ & $\begin{array}{l}\text { kemampuan berpikir kritis } \\
\text { matematis siswa setelah } \\
\text { diterapkan pendekatan saintifik }\end{array}$ \\
\hline
\end{tabular}

Penelitian ini dilakukan di kelas VIII H SMP Negeri 2 Merauke pada semester ganjil tahun pelajaran
2019/2020 dari tanggal 15 November sampai tanggal 29 November 2020. Seluruh siswa kelas VIII SMP Negeri 2 Merauke yang berjumlah 259 orang menjadi populasi penelitian. Kelas VIII $\mathrm{H}$ berjumlah 21 siswa menjadi sampel yang ditentukan dengan teknik cluster random sampling. Peneliti memilih random dari jumlah populasi yang besar, sehingga sampel dipilih berdasarkan kelas. Penggunaan cluster random sampling didasarkan pula untuk menjaga keberadaan sampel dalam pemberian perlakuan. Berdasarkan informasi dari guru matematika SMP Negeri 2 Merauke semua kelas bersifat homogen dan tidak berlaku kelas inti yang artinya siswa dengan kemampuan tinggi atau berprestasi baik berada di dalam kelas yang sama sehingga cukup satu kelas sampel untuk mewakili seluruh kelas VIII. Variabel bebas merupakan pendekatan saintifik dan variabel terikat merupakan kemampuan berpikir kritis matematis. Instrumen yang dipakai untuk pengumpulan data ialah instrumen tes dengan tujuan memeroleh data tentang kemampuan berpikir kritis matematis siswa sebelum dan sesudah diterapkannya pendekatan saintifik.

Signifikansi peningkatan nilai pretest dan posttest dihitung dengan uji $n$-gain score. Menurut Hake (1998) dengan rumus (1).

$$
g=\frac{S_{\text {Post }}-S_{\text {Pre }}}{S_{\text {Maks }}-S_{\text {Pre }}}
$$

Keterangan:

$\mathrm{g}$ = gain score

$\mathrm{S}_{\text {Post }}=$ skor posttest

$\mathrm{S}_{\mathrm{Pre}}=$ skor pretest

$\mathrm{S}_{\text {Maks }}=$ skor maksimal $=100$

Setelah memperoleh $n$-gain score, dilanjutkan dengan menyimpulkan. Kisempulan diambil sesuai dengan 
DOI: https://doi.org/10.24127/ajpm.v9i3.2919

kriteria. Kriteria perolehan $n$-gain score dilihat dalam Tabel 2.

Tabel 2. Kategori n-gain score ternormalisasi.

\begin{tabular}{cl}
\hline Interval & Kategori \\
\hline$g \geq 0,7$ & Tinggi \\
$0,3 \leq g<0,7$ & Sedang \\
$g<0,3$ & Rendah \\
\hline
\end{tabular}

Statistik inferensial dipakai untuk menganalisis hipotesis penelitian yang terdiri atas uji normalitas dan uji hipotesis. Uji prasyarat (uji normalitas) terlebih dahulu dilakukan sebelum menghitung Uji t. Uji normalitas dilakukan guna mengetahui apakah data berdistribusi normal atau tidak. Pengujian normalitas menggunakan metode Kolmogorov-Smirnov dengan taraf signifikansi 5\%. Adapun hipotesis pengujiannya yaitu:

$H_{\mathrm{o}}=$ data dari populasi yang berdistribusi normal.

$H_{\mathrm{a}}=$ data dari populasi yang tidak berdistribusi normal.

Dengan berpedoman jika nilai Asymp.Sig > 0,05 maka $H_{\mathrm{o}}$ diterima atau data berdistribusi normal, sebaliknya jika nilai Asymp.Sig $\leq 0,05$ maka $H_{\mathrm{o}}$ ditolak atau data tidak berdistribusi normal.

Pengujian selanjutnya adalah uji t. Uji $\mathrm{t}$ digunakan untuk membuktikan apakah penerapan pendekatan saintifik berpengaruh terhadap kemampuan berpikir kritis matematis. Rumusan hipotesis statistik untuk uji t, yakni.

$$
\begin{aligned}
& H_{0}: \mu_{1} \geq \mu_{2} \\
& H_{a}: \mu_{1}<\mu_{2}
\end{aligned}
$$

\section{$H_{\mathrm{o}}=$ Kemampuan berpikir kritis} matematis siswa sesudah diterapkan pendekatan saintifik tidak lebih baik atau sama dengan sebelum diterapkan pendekatan saintifik.

$H_{\mathrm{a}}=$ Kemampuan berpikir kritis matematis siswa sesudah diterapkan pendekatan saintifik lebih baik dari sebelum diterapkan pendekatan saintifik.

$\mu_{1}=$ Mean nilai kemampuan awal berpikir kritis matematis siswa.

$\mu_{2}=$ Mean nilai kemampuan akhir berpikir kritis matematis siswa.

Penelitian yang akan dilakukan hanya akan menggunakan satu sampel. Oleh karena itu, rumus (2) yang digunakan dalam Uji t (Subana, 2012) adalah:

$$
t=\frac{M d}{\sqrt{\frac{\Sigma d^{2}-\frac{(\Sigma d)^{2}}{n}}{n(n-1)}}}
$$

Dimana, $M d=\frac{\Sigma d}{n}$

Keterangan:

$M d=$ rata-rata gain (selisih) skor antara pasca tes dan pra tes

$d=$ gain (selisih) skor pasca tes dan pra tes untuk setiap subjek

$n=$ jumlah subjek

Dengan taraf signifikansi: $\alpha=$ $5 \%$, kriteria pengujiannya yaitu:

- Terima $H_{0}$ jika $t_{\text {hitung }} \leq t_{\text {tabel }}$ atau

- Tolak $H_{0}$ jika $t_{\text {hitung }}>t_{\text {tabel }}$, dengan derajat kebebasan $(d f)=$ $(n-1)$.

Setelah membahas tentang pengujian dari data, perlu digarisbawahi bahwa penelitian ini menggunakan indikator kemampuan berpikir kritis sebagai landasa. Indikator kemampuan berpikir kritis siswa didasarkan pada indikator yang dirumuskan oleh (Facione, 2011) yang dapat dilihat pada Tabel 3. 
DOI: https://doi.org/10.24127/ajpm.v9i3.2919

Tabel 3. Indikator kemampuan berpikir kritis matematis.

\begin{tabular}{|c|c|c|}
\hline No. & Komponen & Indikator \\
\hline 1. & Interpretasi & $\begin{array}{l}\text { Siswa memahami masalah ditunjukkan melalui penulisan } \\
\text { informasi yang diketahui dan ditanyakan dari soal dengan tepat. }\end{array}$ \\
\hline 2. & Analisis & $\begin{array}{l}\text { Siswa mengetahui langkah-langkah dalam menyelesaikan soal } \\
\text { ditunjukkan melalui pembuatan model matematika dan memberi } \\
\text { penjelasan yang tepat. }\end{array}$ \\
\hline 3. & Evaluasi & $\begin{array}{l}\text { Siswa menuliskan penyelesaian soal dengan lengkap dan tepat } \\
\text { dalam melakukan perhitungan. }\end{array}$ \\
\hline 4. & Inferensi & $\begin{array}{l}\text { Siswa menarik kesimpulan dari hasil penyelesaian soal dengan } \\
\text { tepat. }\end{array}$ \\
\hline 5. & Eksplanasi & $\begin{array}{l}\text { Siswa menuliskan hasil akhir dan memberikan alasan dari } \\
\text { jawaban yang diberikan. }\end{array}$ \\
\hline 6. & gulasi diri & Siswa memeriksa kembali jawaban yang sudah dituliskan. \\
\hline
\end{tabular}

Adaptasi dari Facione (2011)

\section{HASIL DAN PEMBAHASAN}

Kemampuan berpikir kritis matematis pada penelitian ini dilihat pada saat siswa menyelesaikan soal sistem persamaan linear dua varibel dengan menerapkan interpretasi (siswa mampu menulis informasi yang diberikan dan yang diminta dari soal), analisis (siswa mampu membuat model matematika beserta penjelasannya), evaluasi (siswa mampu menyelesaikan soal beserta perhitungannya), inferensi (siswa mampu membuat kesimpulan sesuai dengan konteks soal yang diberikan), eksplanasi (siswa mampu menuliskan hasil akhir dan memberikan alasan atas jawaban yang telah ditemukan), dan regulasi diri (siswa mampu memeriksa kembali hasil jawaban yang telah ditemukan).

Penelitian ini menerapkan pendekatan saintifik yaitu pembelajaran matematika yang berfokus pada siswa artinya seorang guru hanyalah fasilitator dan siswa dituntut aktif menemukan dan mengolah informasi meliputi kegiatan mengamati, menanya, mencoba, menalar, dan mengomunikasikan. Pelaksanaan penelitian dilakukan selama 4 kali pertemuan yang terdiri atas 3 tahap yaitu tahap pertama pemberian pretest, tahap kedua pelaksanaan pembelajaran dengan penggunaan pendekatan saintifik selama 2 kali pertemuan dan tahap ketiga pemberian posttest. Pada tahap pertama (pemberian pretest), peneliti memberikan tes kepada 21 siswa dengan jumlah tiga soal uraian berdasarkan enam indikator kemampuan berpikir kritis yakni interpretasi, analisis, evaluasi, inferensi, eksplanasi, dan regulasi diri dari materi sistem persamaan linear dua variabel. Kegiatan pretest berjalan dengan baik dan berlangsung selama 2 jam pelajaran, walaupun saat di awal siswa merasa bingung dan kesulitan dalam mengerjakan soal pretest yang diberikan karena belum pernah mempelajari materi yang diberikan.

Setelah melakukan pretest, pada tahap selanjutnya (tahap kedua) yaitu pelaksanaan pembelajaran yang terdiri atas 2 kali pertemuan, pertemuan pertama berlangsung selama 2 jam pelajaran dan pertemuan kedua berlangsung selama 3 jam pelajaran. Kegiatan pembelajaran terbagi menjadi tiga kegiatan yakni kegiatan pendahuluan yang dilakukan peneliti dengan mengondisikan siswa untuk 
DOI: https://doi.org/10.24127/ajpm.v9i3.2919

belajar, memotivasi siswa, dan menyampaikan materi pembelajaran.

Pada kegiatan inti siswa dihadapkan pada suatu masalah atau memberi gambaran materi ajar, memberi kesempatan siswa untuk bertanya, dan membimbing siswa agar dapat menggali informasi, selanjutnya peneliti mengajukan masalah yang tecantum di LKS kepada siswa. LKS yang diberikan memuat masalah sistem persamaan linear dua variabel. Setelah LKS selesai dikerjakan, peneliti meminta seorang siswa untuk menyajikan hasil diskusi kelompoknya, dan siswa yang lain memberikan tanggapan. Selanjutnya peneliti mengajukan pertanyaan terakhir kepada siswa yang lainnya untuk memastikan bahwa indikator pembelajaran benarbenar telah dipahami siswa.

Saat mengerjakan LKS sebagian besar siswa berperan aktif selama proses pengerjaan. Walaupun proses pembelajaran berfokus pada siswa, peneliti tetap memberi bantuan ke siswa yang menghadapi kesulitan saat mengerjakan LKS. Kegiatan penutup dilakukan oleh peneliti dengan penarikan kesimpulan dari materi yang telah didiskusikan, selanjutnya peneliti memberi tugas pekerjaan rumah dan menyampaikan materi yang hendak dipelajari di pertemuan berikutnya. Pada akhir pembelajaran pertemuan kedua peneliti menyampaikan informasi bahwa pertemuan selanjutnya adalah pertemuan terakhir (pemberian posttest).

Pada tahap ketiga (pemberian posttest), diberikan tes kembali ke 21 siswa untuk mendapatkan nilai dari hasil selama pembelajaran sebelumnya dengan jumlah soal yang sama dan sesuai dengan indikator kemampuan berpikir kritis seperti sebelumnya. Kegiatan posttest berjalan dengan baik dan berlangsung selama 2 jam pelajaran. Siswa terlihat lebih santai dan lancar dalam proses pengerjaan soal posttest. Setelah ketiga tahapan selesai dilakukan, hasil dari pretest dan posttest dianalisis untuk melihat adanya pengaruh pendekatan saintifik terhadap kemampuan berpikir kritis matematis pada siswa.

Data yang dideskripsikan meliputi nilai pretest dan posttest. Statistik deskriptif data hasil nilai pretest dan posttest yang ditunjukkan pada Tabel 4 .

Tabel 4. Statistik deskriptif kemampuan berpikir kritis siswa.

\begin{tabular}{ccc}
\hline \multirow{2}{*}{ Statistik } & \multicolumn{2}{c}{ Nilai Statistik } \\
\cline { 2 - 3 } & Pretest & Posttest \\
\hline Banyak sampel & 21 & 21 \\
Nilai Maksimum & 40,30 & 91,00 \\
Nilai minumum & 7,50 & 30,00 \\
Nilai rata-rata & 30,30 & 57,80 \\
Median & 34,00 & 57,00 \\
Varians & 104,94 & 140,34 \\
Standar Deviasi & 10,24 & 11,85 \\
\hline
\end{tabular}

Berdasarkan data pada Tabel 4, diketahui bahwa nilai rata-rata pretest siswa masih rendah dibandingkan nilai mediannya. Hal ini menunjukkan lebih banyak siswa yang memeroleh nilai kurang dari nilai median dibandingkan siswa yang memeroleh nilai lebih dari nilai median. Sedangkan hasil perhitungan posttest menyatakan bahwa nilai rata-rata siswa lebih dari nilai mediannya, yang berarti tidak ada siswa yang memeroleh nilai terlalu rendah atau jauh dari nilai mediannya. Dengan demikian, terlihat bahwa rata-rata nilai siswa meningkat sebesar 27,50.

Selanjutnya dilakukan uji n-gain score. Data hasil uji n-gain score untuk melihat kategori peningkatan yang terjadi pada kemampuan berpikir kritis matematis siswa dengan penerapan pendekatan saintifik dapat dilihat pada Tabel 5. 
DOI: https://doi.org/10.24127/ajpm.v9i3.2919

Tabel 5. Pengkategorian kemampuan berpikir kritis siswa pada uji n-gain score.

\begin{tabular}{lccc}
\hline Interval & Kategori & Banyak Siswa & Frekuensi Relatif \\
\hline$g \geq 0,7$ & Tinggi & 1 & $4,76 \%$ \\
$0,3 \leq g$ & Sedang & 18 & $85,71 \%$ \\
$<0,7$ & Rendah & 2 & $9,52 \%$ \\
$g<0,3$ & & \\
\hline
\end{tabular}

Tabel 5 menunjukkan bahwa satu siswa $(4,76 \%)$ berada di kategori tinggi, siswa yang berkategori sedang sebanyak delapan belas siswa $(85,71 \%)$, dan dua siswa $(9,52 \%)$ berkategori rendah. Dengan demikian, disimpulkan kemampuan berpikir kritis matematis saat pretest dan posttest memiliki perbedaan yang signifikan.

Peneliti selanjutnya melakukan uji prasyarat yaitu uji normalitas data untuk mengetahui apakah data yang diteliti berdistribusi normal atau tidak. Pengujian normalitas data menggunakan metode Kolmogorov-Smirnov melalui program software SPSS 26. Hasil uji normalitas data disajikan pada Tabel 6 .

Tabel 6 Hasil uji normalitas data.

\begin{tabular}{|c|c|c|c|}
\hline \multirow[t]{2}{*}{$\begin{array}{l}\text { Jenis } \\
\text { Data }\end{array}$} & \multirow[t]{2}{*}{$\begin{array}{l}\text { Banyak } \\
\text { Siswa }\end{array}$} & \multicolumn{2}{|c|}{$\begin{array}{c}\text { Kolmogorov- } \\
\text { Smirnov }\end{array}$} \\
\hline & & $\begin{array}{l}\text { Asym. } \\
\text { Sig }\end{array}$ & Interpretasi \\
\hline Pretest & 21 & 0,053 & Normal \\
\hline Posttest & 21 & 0,087 & Normal \\
\hline
\end{tabular}

Tabel 6 menunjukkan bahwa nilai Asymp.Sig $>0,05$ maka $H_{0}$ diterima. Karena itu dapat disimpulkan bahwa data pretest dan posttest berdistribusi normal.

Setelah dilakukan uji normalitas data, peneliti melakukan uji hipotesis yaitu Uji t. Uji ini digunakan untuk membuktikan apakah terdapat pengaruh signifikan pendekatan saintifik terhadap kemampuan berpikir kritis matematis siswa. Hasil Uji t dapat dilihat pada Tabel 7.

Dari Tabel 7 diperoleh $t_{\text {hitung }}=$ 16,965 dan $t_{\text {tabel }}=2,086$ dengan taraf signifikansi $5 \%$ dan $d f=20$. Hasil pengujian hipotesis menunjukkan $t_{\text {hitung }}>t_{\text {tabel }}$, yang berarti $H_{0}$ ditolak dan $H_{a}$ diterima. Hal ini mengindikasikan kemampuan berpikir kritis matematis siswa setelah diterapkan pendekatan saintifik lebih baik dari sebelum diterapkan pendekatan saintifik.

Tabel 7. Hasil uji hipotesis (uji t).

\begin{tabular}{cc}
\hline Statistik & Hasil \\
\hline$d f$ & 20 \\
$\alpha$ & 0,05 \\
$\mathrm{t}_{\text {hitung }}$ & 16,965 \\
$\mathrm{t}_{\text {tabel }}$ & 2,086 \\
\hline
\end{tabular}

Dengan demikian, peneliti membuktikan bahwa pendekatan saintifik memiliki pengaruh yang signifikan terhadap kemampuan berpikir kritis matematis siswa. Hal ini disebabkan oleh pendekatan saintifik memuat aktivitas mengamati, menanya, dan mencoba yang membuat siswa bekerja keras dan berkolaborasi dalam memeroleh dan mencari informasi. Siswa diberi kesempatan untuk mengamati dan menyimak dengan saksama masalah sistem persamaan linear dua variabel (SPLDV) yang disajikan di LKS. Selanjutnya siswa diarahkan untuk mengamati dan melengkapi tabel yang sudah disajikan oleh guru yang memuat konteks kehidupan sehari-hari. Siswa diarahkan membuat pertanyaan yang cocok dengan topik SPLDV dan siswa dibimbing hingga mampu mengajukan pertanyaan secara mandiri. Siswa bereksperimen (mencoba) dalam 
mengumpulkan informasi dari berbagai sumber dan beragam metode. Siswa menggali informasi tentang persamaan linear dua variabel, bagaimana cara mengubah persamaan linear dua variabel menjadi model matematika, bagaimana penyelesaiannya dan seperti apa model matematika dari sistem persamaan linear dua variabel.

Aktivitas menalar membuat siswa mempunyai rasa tanggung jawab terhadap informasi yang telah dikumpulkan untuk membangun alasan disertai bukti yang kuat dan menemukan pola yang menuntun pada penarikan kesimpulan yang valid dari informasi tersebut. Sedangkan pada aktivitas mengomunikasikan, aktivitas diskusi kelompok memungkinkan siswa merasa percaya diri dalam menyampaikan ide atau gagasannya baik secara lisan maupun tulisan dan menghargai pendapat atau tanggapan temannya. Hal ini mendukung penelitian (Wulandari, Dwijanto, \& Sunarmi, 2015) yakni pendekatan saintifik dengan kegiatan diskusi atau berkelompok dapat mendorong kemampuan berpikir kritis dibandingkan dengan pembelajaran konvensional yang jarang dilakukan diskusi dan guru sebagai pusat pembelajaran.

Kelima aktivitas pada pendekatan saintifik menuntun siswa memiliki kesempatan memeroleh pemahaman secara langsung dari konstruksi berpikirnya sendiri dan berbagi pengetahuan atau pemahaman bersama. Aktivitas siswa yang dilakukan untuk mencapai tujuan pembelajaran pada pendekatan saintifik sangat runtut dan sistematis. Dengan demikian, keterlaksanaan kegiatan pembelajaran dengan penerapan pendekatan saintifik dapat meningkatkan kemampuan berpikir kritis matematis pada siswa.
Pendekatan saintifik yang diterapkan di kelas mempunyai pengaruh yang signifikan pada setiap komponen berpikir kristis. Pada komponen interpretasi, rata-rata siswa SMP Negeri 2 Merauke telah memenuhi indikator interpretasi yaitu siswa telah mampu mengategorikan masalah sistem persamaan linear yang diterimanya dengan jelas. Pada komponen analisis, mayoritas siswa mampu mengidentifikasi dan menguraikan masalah SPLDVl yang kompleks menjadi unsur-unsur yang sederhana sehingga lebih mudah dipahami. Selama diskusi dalam pembelajaran di kelas siswa telah memenuhi komponen evaluasi yaitu mampu mempertimbangan berbagai aspek dalam menilai suatu pendapat atau pernyataan yang diperoleh sendiri maupun dari temannya. Pada komponen inferensi, kebanyakan siswa juga mampu mempertimbangkan informasi yang relevan di masalah sehingga dapat membuat suatu kesimpulan dalam memecahkan masalah sistem persaman linear dua variabel yang telah diberikan. Dalam memberikan eksplanasi siswa telah mengonstruksi alasan atau argumen dalam menjelaskan pendapat maupun pernyataan yang sudah diungkapkan sehingga menjadi suatu pendapat yang kuat. Pada komponen regulasi diri, kebanyakan siswa memiliki kesadaran dalam memeriksa atau mengoreksi kembali hasil penalaran yang telah dibuat sebelumnya. Hal ini juga bersesuaian dengan penelitian (Asmi, Fahinu, \& Arapu, 2015) bahwa kelas yang menerapkan pendekatan saintifik menunjukkan hasil kemampuan berpikir kritis siswa yang lebih baik. Penelitian ini juga mendukung penelitian (Fitriana, Yusuf, \& Susanti, 2016) yang mengatakan LKS menggunakan 
pendekatan saintifik mempunyai efek potensial terhadap kemampuan berpikir kritis siswa dalam kategori cukup baik.

\section{KESIMPULAN DAN SARAN}

Berdasarkan paparan pada hasil dan pembahasan dapat disimpulkan bahwa pendekatan saintifik memiliki pengaruh yang signifikan terhadap kemampuan berpikir kritis matematis siswa. Temuan penelitian ini merekomendasikan penerapan pendekatan saintifik bisa digunakan sebagai referensi bagi guru dalam meningkatkan kemampuan berpikir kritis matematis siswa. Kendala saat pelaksanaan pembelajaran dengan pendekatan saintifik di awal pembelajaran penting untuk diidentifikasi agar menghasilkan pembelajaran yang efektif. Guru sebaiknya merancang aktivitas belajar siswa dengan pendekatan saintifik yang memungkinkan siswa berpikir kritis.

\section{DAFTAR PUSTAKA}

As'ari, A. R. (2014). Ideas for Developing Critical Thinking at Primary School Level. In International Seminar on Addressing Higher Order Thinking: Critical Thinking Issues in Primary Education (pp. 1-13). https://doi.org/10.13140/2.1.4534.9 921

Asmar, A., \& Delyana, H. (2020). Hubungan Kemandirian Belajar Terhadap Kemampuan Berpikir Kritis Melalui Penggunaan Software Geogebra. AKSIOMA: Jurnal Program Studi Pendidikan Matematika, 9(2), 221-230.

Asmi, Fahinu, \& Arapu, L. (2015). Pengaruh Pendekatan Scientific Terhadap Kemampuan Berpikir Kritis Siswa Dalam Pembelajaran Matematika Siswa SMPN 2
Kendari. Jurnal Penelitian Pendidikan Matematika, 3(1), 4558.

Fachrurazi. (2011). Penerapan Pembelajaran Berbasis Masalah Untuk Meningkatkan Kemampuan Berpikir Kritis Dan Komunikasi Matematis Siswa Sekolah Dasar. Jurnal Penelitian Pendidikan UPI, (1), 76-89. Retrieved from http://jurnal.upi.edu/penelitianpendidikan/view/637/

Facione, P. a. (2011). Critical Thinking: What It Is and Why It Counts. Insight assessment. Retrieved from https://www.insightassessment.co m/CT-Resources/Teaching-Forand-About-CriticalThinking/Critical-Thinking-WhatIt-Is-and-Why-It-Counts/CriticalThinking-What-It-Is-and-Why-ItCounts-PDF

Fitriana, D., Yusuf, M., \& Susanti, E. (2016). Pengembangan Lembar Kerja Siswa Menggunakan Pendekatan Saintifik Untuk Melihat Berpikir Kritis Siswa Materi Perbandingan. Jurnal Pendidikan Matematika, 10(2), 117.

https://doi.org/10.22342/jpm.10.2. 3629.23-38

Hidayat, W., \& Sari, V. T. A. (2019). Kemampuan Berpikir Kritis Matematis dan Adversity Quotient Siswa SMP. Jurnal Elemen, 5(2), 242.

https://doi.org/10.29408/jel.v5i2.14 54

Kalelioğlu, F., \& Gülbahar, Y. (2013). The effect of instructional techniques on critical thinking and critical thinking dispositions in online discussion. Educational Technology and Society, 17(1), 248-258. 
DOI: https://doi.org/10.24127/ajpm.v9i3.2919

Kriel, C. (2013). Creating a disposition for critical thinking in the mathematics classroom. Proceedings of the Second Biennial Conference of the South African Society for Engineering Education, (11 - 12 June), 67-75.

Kusmanto, H. (2014). Pengaruh Berpikir Kritis Terhadap Kempuan Siswa Dalam Memecahkan Masalah Matematika (Studi Kasus Di Kelas VII SMP Wahid Hasyim Moga). Eduma: Mathematics Education Learning and Teaching, 3(1), 92-106. https://doi.org/10.24235/eduma.v3i 1.6

Miatun, A., \& Khusna, H. (2020). Kemampuan Berpikir Kritis Matematis Berdasarkan Disposisi. AKSIOMA: Jurnal Program Studi Pendidikan Matematika, 9(2), 269-278.

https://doi.org/10.1017/CBO97811 07415324.004

Rochmad, R., Agoestanto, A., \& Kurniasih, A. W. (2016). Analisis Time-Line dan Berpikir Kritis Dalam Pemecahan Masalah
Matematika Pada Pembelajaran Kooperatif Resiprokal. Kreano, Jurnal Matematika KreatifInovatif, $\quad 7(2), \quad 217-231$. https://doi.org/10.15294/kreano.v7i 2.4980

Siti, L. (2020). Profil Berpikir Kritis Calon Guru Matematika Dalam Pembuktian Teorema Geometri. AKSIOMA: Jurnal Program Studi Pendidikan Matematika, 9(1), 190-204.

https://doi.org/10.1017/CBO97811 07415324.004

Sulistyorini, Y., \& Napfiah, S. (2019). Analisis Kemampuan Berpikir Kritis Mahasiswa Dalam Memecahkan Masalah Kalkulus. AKSIOMA: Jurnal Program Studi Pendidikan Matematika, 8(2), 279-287.

Wulandari, N. C., Dwijanto, \& Sunarmi. (2015). Pembelajaran Model REACT Dengan Pendekatan Saintifik Terhadap Kemampuan Berpikir Kritis dan Kerjasama. Unnes Journal of Mathematics Education Research, 4(3), 265-274. 